Article

\title{
Antioxidative Effects of Ascorbic Acid and Astaxanthin on ARPE-19 Cells in an Oxidative Stress Model
}

\author{
Sanghyeon $\mathrm{Oh}^{1,+}$, Young Joo Kim ${ }^{2,+}$, Eun Kyoung Lee ${ }^{3,+} \oplus$, Sung Wook Park ${ }^{3}$ and \\ Hyeong Gon $\mathrm{Yu}^{3, *}$ \\ 1 Interdisciplinary Program in Stem Cell Biology, Graduate School of Medicine, Seoul National University, \\ Seoul 03080, Korea; OhSaHy@hotmail.com \\ 2 Department of Ophthalmology, Seoul National University Hospital Biomedical Research Institute, \\ Seoul 03080, Korea; yjkim612@daum.net \\ 3 Department of Ophthalmology, Seoul National University College of Medicine, Seoul National University \\ Hospital, Seoul 03080, Korea; righthanded8282@gmail.com (E.K.L.); academypark@gmail.com (S.W.P.) \\ * Correspondence: hgonyu@snu.ac.kr; Tel.: +822-2072-3083 \\ + These authors contributed equally to this work.
}

Received: 31 July 2020; Accepted: 3 September 2020; Published: 6 September 2020

\begin{abstract}
Oxidative stress has been implicated as critical pathogenic factors contributing to the etiology of diabetic retinopathy and other retinal diseases. This study investigated antioxidative effect of ascorbic acid and astaxanthin on ARPE-19 cells within an oxidative stress model induced by common biological sources of reactive oxygen species (ROS). Hydrogen peroxide $\left(\mathrm{H}_{2} \mathrm{O}_{2}\right)$ at concentrations of $0.1-0.8 \mathrm{mM}$ and $20-100 \mathrm{~mJ} / \mathrm{cm}^{2}$ of ultraviolet $\mathrm{B}$ (UVB) were treated to ARPE-19 cells. Cell viability and intracellular ROS level changes were measured. With the sublethal and lethal dose of each inducers, $0-750 \mu \mathrm{M}$ of ascorbic acid and $0-40 \mu \mathrm{M}$ of astaxanthin were treated to examine antioxidative effect on the model. Ascorbic acid at concentrations of 500 and $750 \mu \mathrm{M}$ increased the cell viability not only in the UVB model but also in the $\mathrm{H}_{2} \mathrm{O}_{2}$ model, but 20 and $40 \mu \mathrm{M}$ of astaxanthin only did so in the UVB model. The combination of ascorbic acid and astaxanthin showed better antioxidative effect compared to each drug alone, suggesting a synergistic effect.
\end{abstract}

Keywords: antioxidant; ascorbic acid; astaxanthin; oxidative stress; diabetic retinopathy; retinal pigment epithelium; retinal disease

\section{Introduction}

Diabetic retinopathy (DR) is a microvascular consequence of diabetes mellitus and remains the leading cause of blindness among the working-age population [1]. DR is defined as the progressive, irreversible deterioration of retinal microvasculature as a result of chronic hyperglycemia [2] . Studies have found the relationship between oxidative stress and DR that oxidative stress plays a role in pathogenesis of DR and DR can increase the reactive oxygen species (ROS) level. Hyperglycemia is thought to be one of the main causes of the disease and higher level of oxidative stress can accelerate the process by blocking the downstream flow of glycolysis [3,4]. DR also increases oxidative stress because high glucose level and retinal vascularization by diabetic induction elevate arginase activity which later increases oxidative stress [5].

As the relationship between ROS and various retinal pathogenesis have been studied, defense mechanisms against ROS have been also studied [6-11]. Organisms have defense mechanisms against oxygen metabolites and the mechanism includes removal of free radicals by enzymes, proteins, and pro-oxidant metal reactions, and reduction of free radicals by antioxidants (vitamin C, vitamin E, 
glutathione) [6]. The cellular antioxidant response element is essentially important for the amelioration of oxidative stress. It responds to hyperglycemia and can be used to evaluate the complications of diabetes. In a previous study, Busik et al. [12] suggested that diabetes-related endothelial injury in the retina may be due to glucose-induced cytokine release by other retinal cells, such as retinal pigment epithelium (RPE) and Müller cells, and not a direct effect of high glucose. Therefore, it is important to investigate the oxidative stress as well as effects of antioxidants on RPE cells in order to determine the pathogenesis regarding oxidative stress in DR.

Studies have found that with aging, endogenous antioxidants level [13] and antioxidant enzyme activity along with its gene expression and protein level decrease [14]. This alteration in the antioxidative defense system worsens the imbalance between ROS production and its removal. As a consequence, oxidatively damaged macromolecules including lipids, deoxyribonucleic acid (DNA), and proteins accumulate accelerating the aging process with oxidative-stress-induced aging [15].

For this reason, it becomes more important to maintain the antioxidant defense system and one way is to supplement antioxidants from an outer source. Supplements actively studied for their antioxidative effect are ascorbic acid (vitamin C), glutathione, alpha-tocopherol (vitamin E), and other carotenoids (i.e., astaxanthin, lutein, $\beta$-carotene) [16-18]. One frequently used way to evaluate their antioxidant activity is by studying their reactivity with free radicals and metal ions (DPPH, ABTS, FRAP, CUPRAC, ORAC, HORAC, TRAP) [19-22]. However, giving them enough credence for their antioxidant capacity assumption is often controversial since one same antioxidant can have a different relative capacity to other antioxidants when measured with different methods [23-28].

For this reason, it is necessary to study potential antioxidants' capacities and properties based on a solid oxidative stress model. A solid oxidative stress model portrays the biological environment well so that a more accurate assumption is possible, and the result is reproducible. Hydrogen peroxide $\left(\mathrm{H}_{2} \mathrm{O}_{2}\right)$ [29-31] and ultraviolet $\mathrm{B}$ (UVB) irradiation [32-34] have been studied to establish an oxidative stress model within cells. $\mathrm{H}_{2} \mathrm{O}_{2}$ represents endogenous ROS production and UVB represents an outer source of oxidative stress to retinal cells. In this study, both a $\mathrm{H}_{2} \mathrm{O}_{2}$-induced oxidative stress model and UVB-induced oxidative stress model will be used to evaluate the antioxidative potential of ascorbic acid and astaxanthin on ARPE-19 cells.

\section{Materials and Methods}

\subsection{ARPE-19 Cell Culture}

ARPE-19 cells (american type culture collection, Manassas, VA, USA) were cultured and maintained as a monolayer in 1:1 mixture of Dulbecco's modified eagle's medium and nutrient mixture F-12 (DMEM/F-12) (Invitrogen, Gibco, Carlsbad, CA, USA) supplemented with $10 \%$ fetal bovine serum (FBS) (Invitrogen) and 1\% penicillin-streptomycin (Invitrogen). Cells were incubated at $37{ }^{\circ} \mathrm{C}$ in a humidified $5 \% \mathrm{CO}_{2}$ incubator in the complete medium with a 2-3-times-a-week change until they reached $80 \%$ confluency. Cells used for this study were in a passage between 25 and 30 .

\subsection{Hydrogen Peroxide Exposure Procedure}

Cells were seeded in a 96-well plate with a density of $2.5 \times 10^{4}$ cells/well and allowed to attach to the bottom of the well and to become confluent overnight. The next day, the medium was changed to a serum-free medium and cells were maintained in it up to 7 days until the day of the procedure. $30 \%(w / w) \mathrm{H}_{2} \mathrm{O}_{2}$ in $\mathrm{H}_{2} \mathrm{O}$-containing stabilizer (Sigma Aldrich, St. Louis, MO, USA) was used to make medium with intended $\mathrm{H}_{2} \mathrm{O}_{2}$ concentration. $\mathrm{H}_{2} \mathrm{O}_{2}$ solution was diluted fresh each time. For the exposure, the used medium of the cells was changed to serum-free DMEM/F-12 without phenol red (Invitrogen) with the desired concentration of $\mathrm{H}_{2} \mathrm{O}_{2}$. The viability was checked by MTT assay after $24 \mathrm{~h}$ of exposure to $\mathrm{H}_{2} \mathrm{O}_{2}$. 


\subsection{Ultraviolet B Irradiation Procedure}

Cells were seeded in a 96-well plate with a density of $2.5 \times 10^{4}$ cells/well and allowed to attach to the bottom of the well and to become confluent overnight. The next day, the medium was changed to serum-free medium and cells were maintained in it up to 7 days until the day of the procedure. At UVB irradiation, the medium was changed to DMEM/F-12 without phenol red without serum. As a UVB source, Sankyo Denki lamps (G15T8E, Tokyo, Japan) was used. Its irradiation intensity was $0.2 \mathrm{~mW} / \mathrm{cm}^{2}$ when measured $20 \mathrm{~cm}$ below the lamp where the plates were put. The intensity was measured with a UVB meter (UVX Digital Radiometer, UVP, Upland, CA, USA). Cells were irradiated with intended doses of UVB and for the control group and differential dose of UVB irradiation, remaining wells in the same plate were thoroughly masked.

\subsection{DPPH Scavenging Assay}

Total antioxidative capacities of ascorbic acid and astaxanthin were estimated using DPPH (2,2-diphenyl-1-picrylhydrazyl) ROS scavenging assay. DPPH solution was made by dissolving DPPH in methanol to $0.16 \mathrm{mM}$. Ascorbic acid and astaxanthin were dissolved to various concentrations in dimethyl sulfoxide (DMSO) (Sigma Aldrich). Ascorbic acid $(20 \mu \mathrm{L})$ or astaxanthin $(20 \mu \mathrm{L})$ solution was mixed with $100 \mu \mathrm{L}$ DPPH solution for $30 \mathrm{~min}$ with vigorous shaking at room temperature. After the reaction absorbance at $517 \mathrm{~nm}$ was measured and the relative amount of scavenged DPPH was calculated using the following equation.

$$
\text { Scavenged DPPH fraction }(\%)=\frac{A b_{\text {Control }}-A b_{A O}}{A b_{\text {Control }}} \times 100
$$

$A b_{\text {Control }}$ is the absorbance of the groups with only DPPH and $A b_{A O}$ is the absorbance of the groups of the mixture of DPPH and various concentrations of antioxidants.

\subsection{Antioxidant Treatment}

Cells were treated with either ascorbic acid (Sigma Aldrich) or astaxanthin (Sigma Aldrich) in DMEM/F-12 without phenol red to study their antioxidative effect on ARPE-19 cells. Ascorbic-acid-containing medium was made from ascorbic acid stock (0.5 $\mathrm{M}$ in PBS) and astaxanthin-containing medium was made from astaxanthin stock ( $1 \mathrm{mg} / \mathrm{mL}$ in DMSO). Cells were pretreated with ascorbic acid or astaxanthin for $6 \mathrm{~h}$ and then they were irradiated by UVB or exposed to $\mathrm{H}_{2} \mathrm{O}_{2}$. For UVB irradiation group, after pretreatment, used medium was changed to the fresh medium containing the same concentrations of compounds and followed the UVB irradiation $\left(20 \mathrm{~mJ} / \mathrm{cm}^{2} \mathrm{or}\right.$ $100 \mathrm{~mJ} / \mathrm{cm}^{2}$ ) procedure. For the $\mathrm{H}_{2} \mathrm{O}_{2}$ exposure group, after pretreatment, the used medium was changed to the fresh medium containing the same concentrations of the compounds with a sublethal or lethal dose of $\mathrm{H}_{2} \mathrm{O}_{2}(0.2 \mathrm{mM}$ or $0.4 \mathrm{mM})$.

\subsection{MTT Assay}

3-(4,5-Dimethyl-2-thiazolyl)-2,5-diphenyl-2H-tetrazolium bromide (MTT) (Sigma Aldrich) was used to determine cell viability. MTT is enzymatically turned into purple formazan crystals by mitochondrial respiration activity. The procedure was done following the manufacturer's instructions. Briefly, after antioxidants, $\mathrm{UVB}$, or $\mathrm{H}_{2} \mathrm{O}_{2}$ treatment to the cells, the medium was removed and MTT $(0.5 \mathrm{mg} / \mathrm{mL})$ was added diluted in serum-free medium. After $3 \mathrm{~h}$ of incubation at $37{ }^{\circ} \mathrm{C}$ in a humidified $5 \% \mathrm{CO}_{2}$ incubator, MTT-containing medium was carefully aspirated from the well and DMSO was added to each well to solubilize formazan crystals. Absorbance at $570 \mathrm{~nm}$ was measured using a microplate reader (EPOCH 2, BioTek Instruments Inc. Winoosky, VT, USA) with a reference wavelength of $630 \mathrm{~nm}$. Cells untreated or treated with the only vehicle were set to be $100 \%$ cell viability for the normalization of the absorbance and experiments had more than three replicates for each condition. 


\subsection{Crystal Violet Assay}

The relative number of cells attached to the bottom of the well was measured by crystal violet uptake assay. The procedure was done as previously described [35]. Briefly, after UVB, or $\mathrm{H}_{2} \mathrm{O}_{2}$ treatment to the cells, the medium was removed, and cells were fixed with $4 \%$ paraformaldehyde in $4{ }^{\circ} \mathrm{C}$. After they were washed 3 times and $0.1 \%$ crystal violet (Sigma Aldrich) in $10 \%$ ethanol was added to each well for $5 \mathrm{~min}$. After washing 3 times, the remaining stain was dissolved in $10 \%$ acetic acid and absorbance at $540 \mathrm{~nm}$ was measured.

\subsection{DCFH-DA Intracellular ROS Level Assay}

Intracellular ROS level was measured by $2^{\prime}, 7^{\prime}$-dichlorodihydrofluorescein diacetate (DCFH-DA) assay. DCFH-DA is cell-permeable and is not fluorescent which enters cells to be de-esterified to $2^{\prime}, 7^{\prime}$-dichlorodihydrofluorescein (DCFH), and become impermeable to the cell membrane. It then reacts with ROS to be highly fluorescent $2^{\prime}, 7^{\prime}$-dichlorofluorescein (DCF). Before UVB irradiation or $\mathrm{H}_{2} \mathrm{O}_{2}$ exposure, cells were cultured with $10 \mu \mathrm{M}$ DCFH-DA (Sigma Aldrich) in DMEM/F-12 without phenol red for $30 \mathrm{~min}$ at $37^{\circ} \mathrm{C}$ in a humidified $5 \% \mathrm{CO}_{2}$ incubator. After incubation, they were washed 2 times in phosphate-buffered saline (PBS) and antioxidant treatment, UVB irradiation or $\mathrm{H}_{2} \mathrm{O}_{2}$ exposure was done following measurement of fluorescence of DCF at excitation and emission wavelength of $495 \mathrm{~nm}$ and $529 \mathrm{~nm}$, respectively, with a microplate reader (Synergy Mix, BioTek Instruments Inc. Winoosky, VT, USA). Cells untreated or treated with the only vehicle were set to be $100 \%$ intracellular ROS level for the normalization of the fluorescence intensity and experiments had more than three replicates for each condition.

\subsection{Statistical Analysis}

The results were expressed as mean values and standard deviation (SD). Statistical analyses were performed using the Kruskal-Wallis test for comparison between several groups and the Mann-Whitney $U$ test for comparison between 2 subgroups to assess the effects of drug treatment, with $p<0.05$. The analyses were done using IBM SPSS Statistics for Windows, Version 26.0 (IBM Corp., Armonk, New York, NY, USA).

\section{Results}

\subsection{Effect of $\mathrm{H}_{2} \mathrm{O}_{2}$ on the Viability of ARPE-19 Cells and Intracellular ROS Level}

To establish the $\mathrm{H}_{2} \mathrm{O}_{2}$-induced oxidative stress model in ARPE-19 cells, different concentrations of $\mathrm{H}_{2} \mathrm{O}_{2}$ were treated to the cells and their viability and intracellular ROS level were measured. Viability measured with MTT assay decreased as the concentration of treated $\mathrm{H}_{2} \mathrm{O}_{2}$ increased. When cells were treated with $0.4 \mathrm{mM} \mathrm{H}_{2} \mathrm{O}_{2}$, they showed the viability of $66 \%$ and the viability change was the greatest between $0.2 \mathrm{mM}$ and $0.6 \mathrm{mM}$ (Figure 1A). Crystal violet assay resulted in a similar aspect of viability change as MTT assay with $69 \%$ of viability at $0.4 \mathrm{mM}$ (Figure 1B). Intracellular ROS level increased dependently to the concentration of $\mathrm{H}_{2} \mathrm{O}_{2}$ (Figure 1C). The mean value of the ROS level measured in $0.8 \mathrm{mM} \mathrm{H}_{2} \mathrm{O}_{2}$ increased to $176 \%$ compared to the control group. This trend of decreased cell viability after the $\mathrm{H}_{2} \mathrm{O}_{2}$ exposure was confirmed in bright field imaging (Figure 1D,E). As cell viability changed rapidly at $0.4 \mathrm{mM} \mathrm{H}_{2} \mathrm{O}_{2}, 0.4 \mathrm{mM}$ was set to be a lethal dose of $\mathrm{H}_{2} \mathrm{O}_{2}$ and $0.2 \mathrm{mM}$ was set to be sublethal dose. 

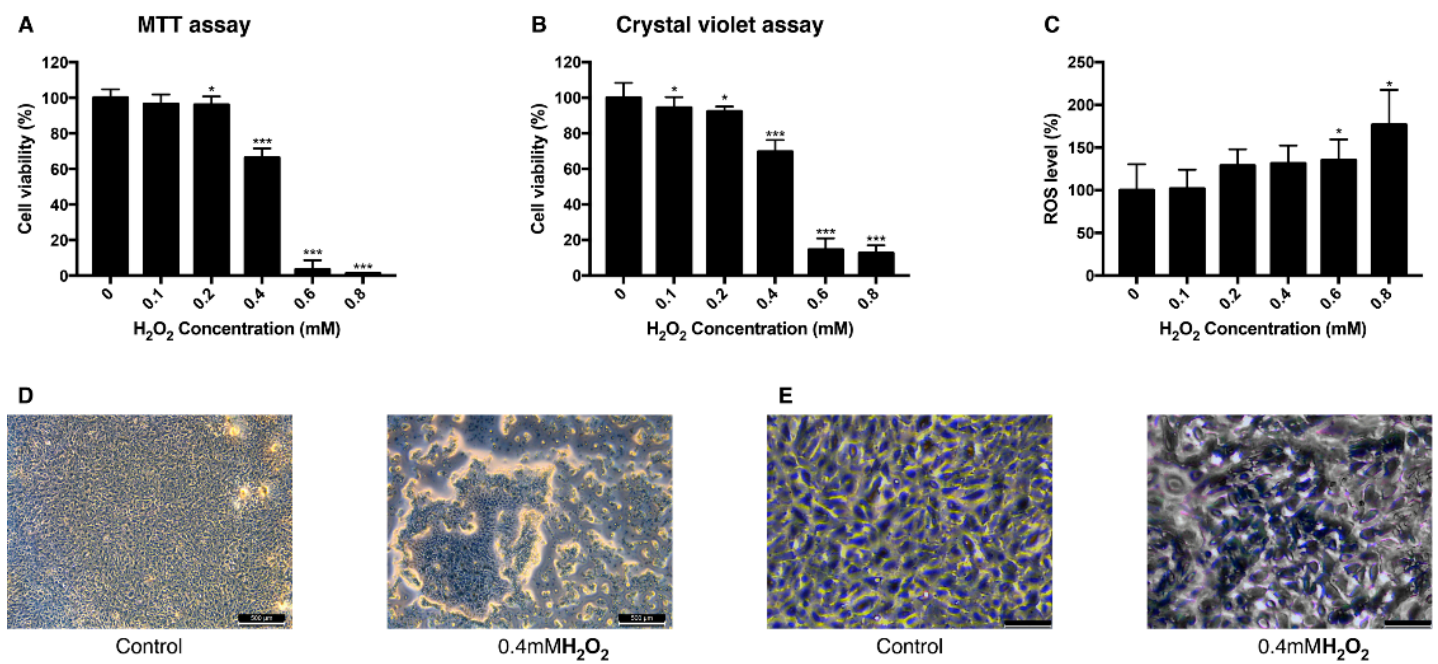

Figure 1. Change of viability and intracellular ROS level in ARPE-19 cells after exposure to $\mathrm{H}_{2} \mathrm{O}_{2}$. The response of ARPE-19 cells to $0-0.8 \mathrm{mM} \mathrm{H}_{2} \mathrm{O}_{2}$ exposure for MTT assay (A), and crystal violet assay (B) to determine cell viability. For intracellular ROS level, DCFH-DA was treated for $30 \mathrm{~min}$ after the $\mathrm{H}_{2} \mathrm{O}_{2}$ exposure. Exposure to $\mathrm{H}_{2} \mathrm{O}_{2}$ reduced the cell viability $(\mathbf{A}, \mathbf{B})$ and increased the intracellular ROS level (C). The cell morphology was observed with bright field microscopy (Scale bar $500 \mu \mathrm{m})(\mathrm{D})$ and with higher magnification (scale bar $100 \mu \mathrm{m})($ E). Asterisks indicate a significant reduction in cell viability or increment in ROS level compared with untreated cells $\left(^{*} p<0.05,{ }^{* *} p<0.01,{ }^{* * *} p<0.001\right)$. MTT, 3-(4,5-dimethylthiazol-2-yl)-2,5-diphenyltetrazolium bromide; ROS, reactive oxygen species; DCFH-DA, 2' $2^{\prime} 7^{\prime}$-dichlorodihydrofluorescein diacetate.

\subsection{Effect of UVB Irradiation on the Viability of ARPE-19 Cells and Intracellular ROS}

To establish the UVB-induced oxidative stress model in ARPE-19 cells, different doses of UVB were exposed to the cells and their viability and intracellular ROS level were measured. Viability measured with MTT assay decreased as the dose of UVB irradiation increased. When cells were exposed to $20 \mathrm{~mJ} / \mathrm{cm}^{2} \mathrm{UVB}$, they showed the viability of $80 \%$ and with $100 \mathrm{~mJ} / \mathrm{cm}^{2} \mathrm{UVB}$, the viability was $60 \%$ (Figure $2 \mathrm{~A}$ ). In a crystal violet assay with the same range of UVB dose, the viability dropped to $78 \%$ at $20 \mathrm{~mJ} / \mathrm{cm}^{2} \mathrm{UVB}$ and to $72 \%$ at $100 \mathrm{~mJ} / \mathrm{cm}^{2} \mathrm{UVB}$ (Figure 2B). Intracellular ROS level increased dependently to the UVB dose (Figure 2C). The mean value of ROS level measured at $20 \mathrm{~mJ} / \mathrm{cm}^{2} \mathrm{UVB}$ increased to $140 \%$ and $270 \%$ at $100 \mathrm{~mJ} / \mathrm{cm}^{2} \mathrm{UVB}$ compared to the control group. Morphological change of the cells was observed in bright field imaging. Cells became rounder and holes in the monolayer were observed as UVB dose increased (Figure 2D,E). The sublethal dose of UVB was set to be $20 \mathrm{~mJ} / \mathrm{cm}^{2}$, where the cells show $80 \%$ of viability without significant morphological change and $100 \mathrm{~mJ} / \mathrm{cm}^{2}$ where the cells show $60 \%$ of viability with morphological change was set to be the lethal dose of UVB. 

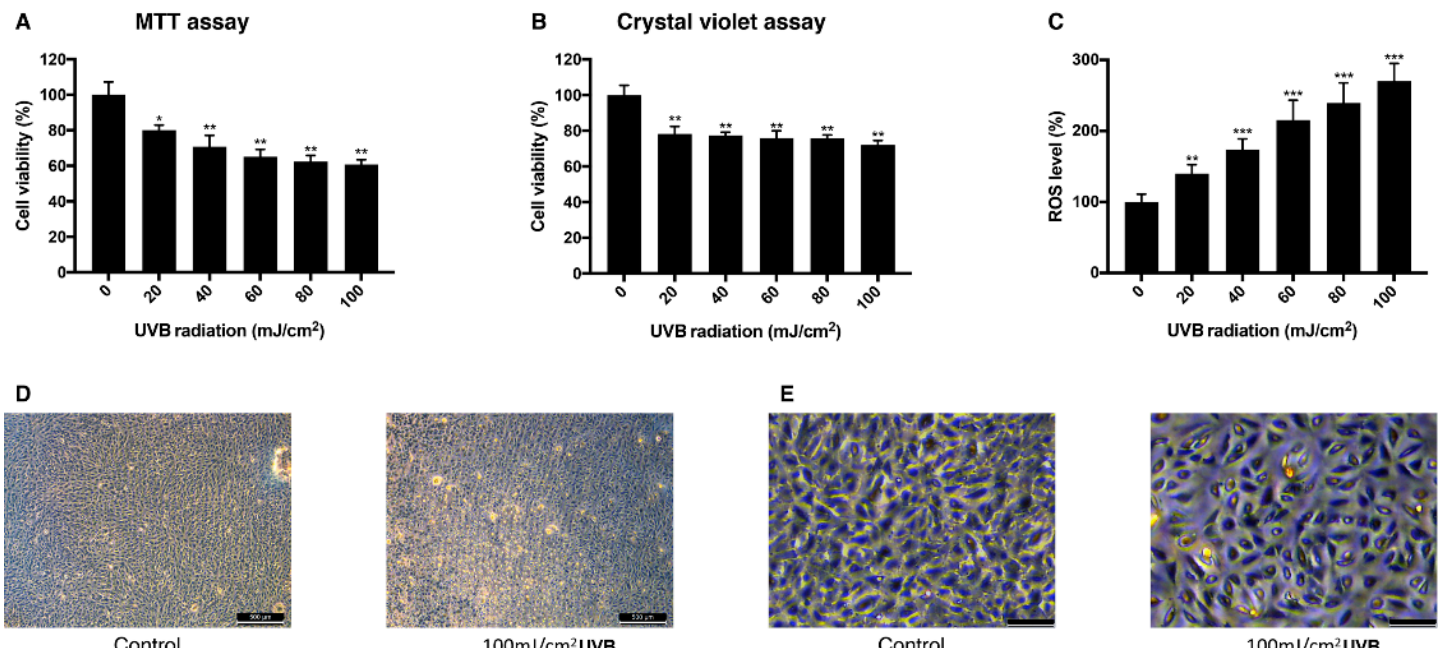

Control

$100 \mathrm{~mJ} / \mathrm{cm}^{2}$ UVB

Figure 2. Change of viability and intracellular ROS level in ARPE-19 cells after UVB irradiation. The response of ARPE-19 cells $24 \mathrm{~h}$ after 0-100 mJ/ $\mathrm{cm}^{2}$ UVB irradiation with MTT assay (A), and crystal violet assay (B) to determine cell viability. For intracellular ROS level, DCFH-DA was treated for $30 \mathrm{~min}$ after the UVB irradiation. Irradiation by UVB reduced the cell viability $(\mathbf{A}, \mathbf{B})$ and increased the intracellular ROS level (C). The cell morphology was observed with bright field microscopy (scale bar $500 \mu \mathrm{m})(\mathrm{D})$ and with higher magnification (scale bar $100 \mu \mathrm{m})($ E). Asterisks indicate a significant reduction in cell viability or increment in ROS level compared with untreated cells $\left({ }^{*} p<0.05,{ }^{* *} p<0.01\right.$, *** $p<0.001)$. UVB, ultraviolet B; MTT, 3-(4,5-dimethylthiazol-2-yl)-2,5-diphenyltetrazolium bromide; ROS, reactive oxygen species; DCFH-DA, $2^{\prime}, 7^{\prime}$-dichlorodihydrofluorescein diacetate.

\subsection{Antioxidative Effect of Ascorbic Acid and Astaxanthin by Scavenging DPPH}

DPPH scavenging assay was performed with ascorbic acid and astaxanthin. Ascorbic acid, at concentrations of $0.025 \mathrm{mM}, 0.1 \mathrm{mM}, 0.4 \mathrm{mM}$, and $1.6 \mathrm{mM}$, dissolved in DMSO was mixed with DPPH solution and each concentration scavenged $33 \%, 52 \%, 57 \%, 73 \%$ of DPPH, respectively, after $30 \mathrm{~min}$ of reaction (Figure 3A). When $75 \mu \mathrm{M}, 85 \mu \mathrm{M}, 95 \mu \mathrm{M}$, and $105 \mu \mathrm{M}$ astaxanthin dissolved in DMSO were reacted with DPPH solution for $30 \mathrm{~min}, 44 \%, 50 \%, 64 \%$, and $69 \%$ of DPPH were scavenged, respectively (Figure 3B). Both ascorbic acid and astaxanthin showed antioxidative effect.

A

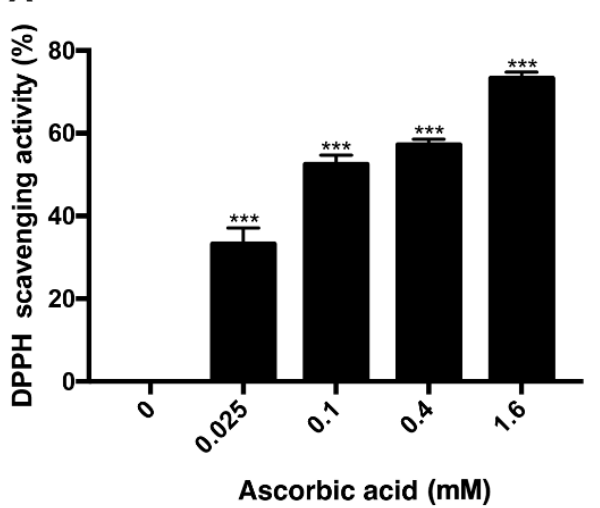

B

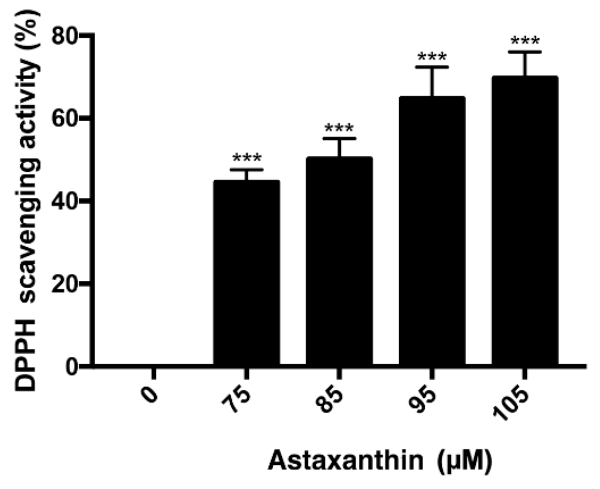

Figure 3. DPPH scavenging activity of ascorbic acid and astaxanthin. The antioxidative capacities of ascorbic acid and astaxanthin were determined by their capabilities to scavenge DPPH. Ascorbic acid (0.025-1.6 mM) was reacted with DPPH (A), and astaxanthin $(75-105 \mu \mathrm{M})$ was reacted with DPPH (B). The compounds were diluted in DMSO. Both compounds scavenged DPPH in dose-dependent way in 30 min of reaction time. Asterisks indicate a significant increment in DPPH scavenging activity compared with controls (** $p<0.001$ ). DPPH, 2,2-diphenyl-1-picrylhydrazyl; DMSO, dimethyl sulfoxide. 


\subsection{Antioxidative Effect of Ascorbic Acid on ARPE-19 Cells Under $\mathrm{H}_{2} \mathrm{O}_{2}$-Induced Oxidative Stress}

ARPE-19 cells were pretreated with various concentrations of ascorbic acid or astaxanthin for $6 \mathrm{~h}$ and then they were treated together with $\mathrm{H}_{2} \mathrm{O}_{2}$ and the same concentrations of antioxidants for another $24 \mathrm{~h}$. Viability was assessed after $3 \mathrm{~h}$ of MTT treatment. When groups treated together with ascorbic acid and $\mathrm{H}_{2} \mathrm{O}_{2}$ they showed increased viability compared to controls. Cells treated only with $0.2 \mathrm{mM} \mathrm{H}_{2} \mathrm{O}_{2}$ showed the viability of $80 \%$ and groups treated together with ascorbic acid showed $81 \%$, $107 \%$, and $126 \%$ of viability, respectively, for $250 \mu \mathrm{M}, 500 \mu \mathrm{M}$, and $750 \mu \mathrm{M}$ of the drug concentration. On the other hand, astaxanthin did not show any significant effect on the viability of ARPE-19 with $\mathrm{H}_{2} \mathrm{O}_{2}$-induced oxidative stress (Figure 4A). For $0.4 \mathrm{mM} \mathrm{H}_{2} \mathrm{O}_{2}$ treatment, cells treated only with $\mathrm{H}_{2} \mathrm{O}_{2}$ showed $58 \%$ of viability, while $250 \mu \mathrm{M}, 500 \mu \mathrm{M}$, and $750 \mu \mathrm{M}$ of ascorbic acid increased the viability to $64 \%, 72 \%$, and $95 \%$, respectively. On the other hand, astaxanthin did not show any significant effect on the viability of ARPE-19 with $\mathrm{H}_{2} \mathrm{O}_{2}$-induced oxidative stress (Figure 4B).
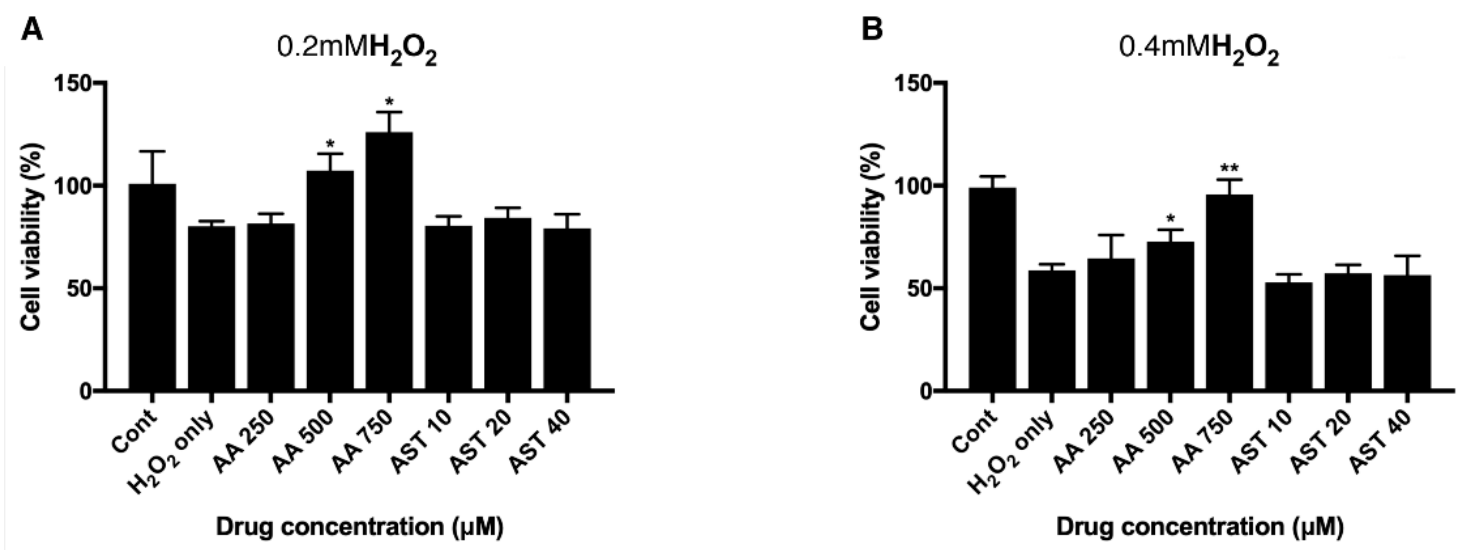

Figure 4. Effect of ascorbic acid and astaxanthin on $\mathrm{H}_{2} \mathrm{O}_{2}$-induced oxidative stress model of ARPE-19. The effect of various concentration of ascorbic acid or astaxanthin (pretreated for $6 \mathrm{~h}$ and co-treated with $\mathrm{H}_{2} \mathrm{O}_{2}$ for $24 \mathrm{~h}$ ) on the response of ARPE-19 cells to sublethal dose of $0.2 \mathrm{mM}$ (A) or lethal dose of $0.4 \mathrm{mM} \mathrm{H}_{2} \mathrm{O}_{2}$ (B). The cell viability was determined by MTT assay. Treatment of ascorbic acid (500-750 $\mu \mathrm{M}$ ) significantly increased ARPE-19 cell viability following $0.2 \mathrm{mM} \mathrm{H}_{2} \mathrm{O}_{2}$ exposure. However, astaxanthin $(10-40 \mu \mathrm{M})$ did not significantly affect the cell viability (A). Ascorbic acid (500-750 $\mu \mathrm{M})$ also significantly increased the cell viability under $0.4 \mathrm{mM} \mathrm{H}_{2} \mathrm{O}_{2}$ but astaxanthin $(10-40 \mu \mathrm{M})$ did not have significant effect on the viability $(\mathbf{B})$. Asterisks indicate a significant increment in cell viability compared with cells treated with $\mathrm{H}_{2} \mathrm{O}_{2}$ only ( $p<0.05$, $\left.{ }^{* *} p<0.01\right)$. AA, ascorbic acid; AST, astaxanthin; MTT, 3-(4,5-dimethylthiazol-2-yl)-2,5-diphenyltetrazolium bromide.

\subsection{Antioxidative Effect of Ascorbic Acid and Astaxanthin on ARPE-19 Cells Under UVB-induced Oxidative Stress}

ARPE-19 cells were pretreated with various concentrations of ascorbic acid or astaxanthin for $6 \mathrm{~h}$ and then they were irradiated with UVB. Viability $24 \mathrm{~h}$ after the irradiation was assessed with MTT assay. When cells were pretreated with ascorbic acid and then UVB irradiated with it, the cell viability increased compared to the UVB irradiation-only group. Cells irradiated only with $20 \mathrm{~mJ} / \mathrm{cm}^{2}$ UVB showed the viability of 85\% and groups treated together with ascorbic acid showed 92\%, 102\%, and $130 \%$ of viability, respectively, for $250 \mu \mathrm{M}, 500 \mu \mathrm{M}$, and $750 \mu \mathrm{M}$ of the drug concentration. Astaxanthin treated cells also showed increased viability compared to the cells irradiated only with UVB. The $10 \mu \mathrm{M}, 20 \mu \mathrm{M}$, and $40 \mu \mathrm{M}$ astaxanthin groups showed 95\%, 101\%, and 102\%, respectively, after $20 \mathrm{~mJ} / \mathrm{cm}^{2}$ UVB irradiation (Figure 5A). For $100 \mathrm{~mJ} / \mathrm{cm}^{2} \mathrm{UVB}$ irradiation, the cells irradiated only with UVB showed $66 \%$ of viability while $250 \mu \mathrm{M}, 500 \mu \mathrm{M}$, and $750 \mu \mathrm{M}$ of ascorbic acid increased the viability to $68 \%, 78 \%$, and $109 \%$, respectively. Astaxanthin-treated cells also showed increased viability 
compared to the cells irradiated only with UVB. The $10 \mu \mathrm{M}, 20 \mu \mathrm{M}$, and $40 \mu \mathrm{M}$ astaxanthin groups showed $67 \%, 74 \%$, and $83 \%$ after $100 \mathrm{~mJ} / \mathrm{cm}^{2}$ UVB irradiation (Figure $5 \mathrm{~B}$ ).
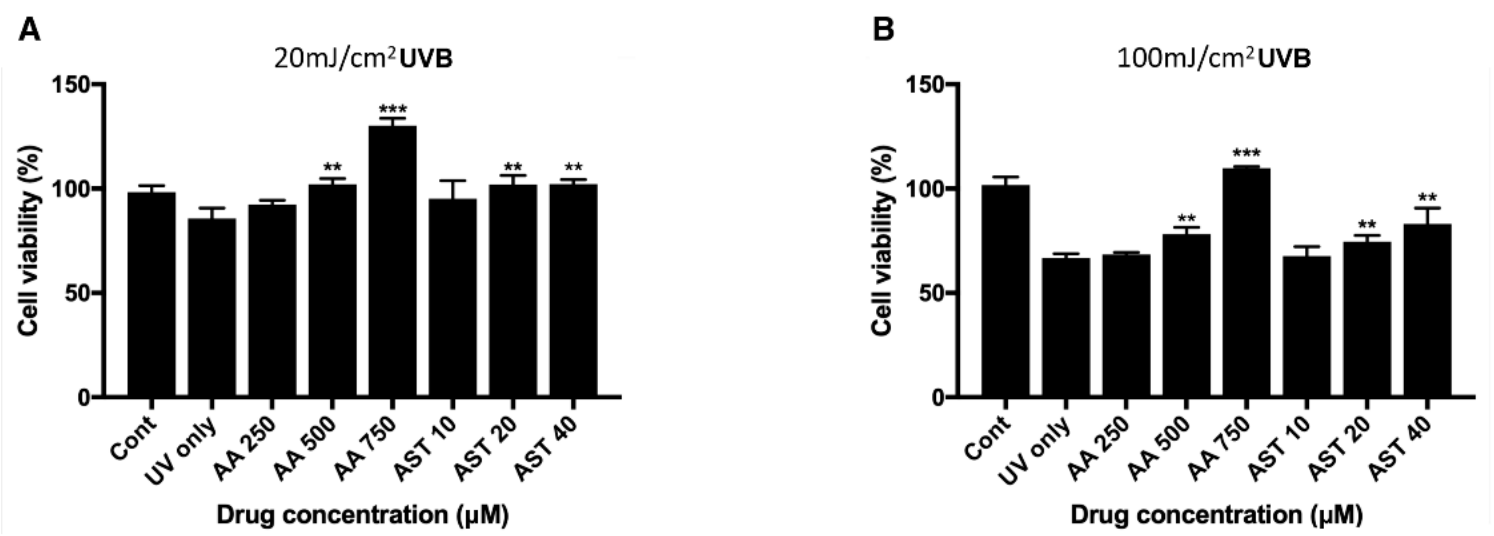

Figure 5. Effect of ascorbic acid and astaxanthin on UVB-induced oxidative stress model of ARPE-19. The effect of various concentration of ascorbic acid and astaxanthin (pretreated for $6 \mathrm{~h}$ and additional $24 \mathrm{~h}$ after UVB irradiation) on the response of ARPE-19 cells to sublethal dose of $20 \mathrm{~mJ} / \mathrm{cm}^{2}$ (A) or lethal dose of $100 \mathrm{~mJ} / \mathrm{cm}^{2}$ UVB (B). The cell viability was determined by MTT assay $24 \mathrm{~h}$ after the irradiation. Treatment of ascorbic acid $(500-750 \mu \mathrm{M})$ and astaxanthin $(20-40 \mu \mathrm{M})$ significantly increased ARPE-19 cell viability following $20 \mathrm{~mJ} / \mathrm{cm}^{2}$ UVB irradiation (A). Ascorbic acid (500-750 $\mathrm{MM}$ ) and astaxanthin (20-40 $\mu \mathrm{M})$ also significantly increased the cell viability after $100 \mathrm{~mJ} / \mathrm{cm}^{2} \mathrm{UVB}$ irradiation (B). Asterisks indicate a significant increment in cell viability compared with cells treated with UVB only ( $\left.{ }^{*} p<0.05,{ }^{* *} p<0.01,{ }^{* * *} p<0.001\right)$. UVB, ultraviolet B; AA, ascorbic acid; AST, astaxanthin; MTT, 3-(4,5-dimethylthiazol-2-yl)-2,5-diphenyltetrazolium bromide.

\subsection{Effect of Ascorbic Acid on the Intracellular ROS Level of ARPE-19}

The effect of ascorbic acid on the intracellular ROS level of ARPE-19 cells was studied with DCFH-DA assay. The intracellular ROS level was measured after cells were treated with UVB with or without $500 \mu \mathrm{M}$ ascorbic acid. UVB of $20 \mathrm{~mJ} / \mathrm{cm}^{2}$ and $100 \mathrm{~mJ} / \mathrm{cm}^{2}$ increased the intracellular ROS level to $123 \%$ and $234 \%$, respectively, and $500 \mu \mathrm{M}$ ascorbic acid treatment reduced the ROS level to $105 \%$ and $115 \%$ (Figure 6A). This trend between groups were confirmed with fluorescence microscopy (Figure 6B). 
A

B

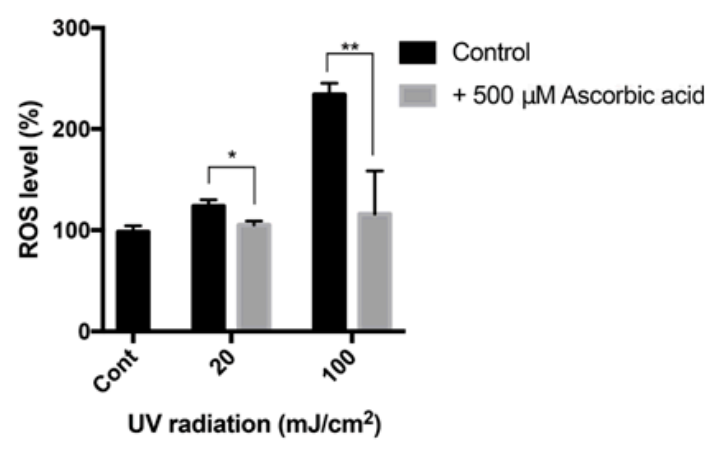

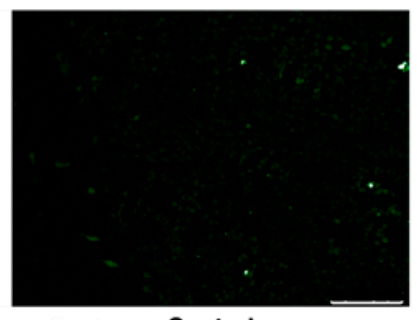

Control

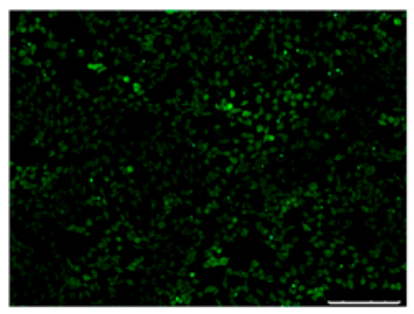

$100 \mathrm{~mJ} / \mathrm{cm}^{2}$

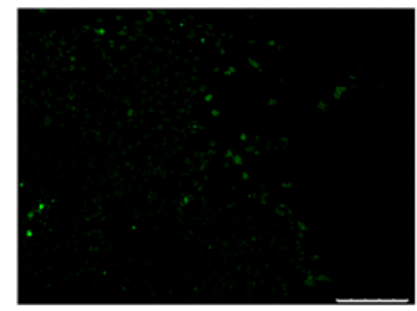

$100 \mathrm{~mJ} / \mathrm{cm}^{2}+500 \mathrm{uM} \mathrm{AA}$

Figure 6. Intracellular ROS level of ARPE-19 after UVB treatment with ascorbic acid. The effects of ascorbic acid on the intracellular ROS level of ARPE-19 under UVB-induced oxidative stress were examined by DCFH-DA assay. Ascorbic acid at $500 \mu \mathrm{M}$ significantly reduced the ROS level after UVB irradiation (20-100 mJ/cm²) compared to groups with UVB irradiation only (A). The green fluorescence of the reacted DCFH-DA which indicates the ROS level, was observed with fluorescence microscopy (scale bar $250 \mu \mathrm{m}$ ) (B). Asterisks indicate a significant reduction in ROS level compared with control cells only with UVB exposure without ascorbic acid treatment $\left({ }^{*} p<0.05,{ }^{* *} p<0.01\right)$. ROS, reactive oxygen species; UVB, ultraviolet B; DCFH-DA, $2^{\prime}, 7^{\prime}$-dichlorodihydrofluorescein diacetate; AA, ascorbic acid.

\subsection{Antioxidative Effect of Astaxanthin and Ascorbic Acid by Reducing Intracellular ROS in ARPE-19 Cells}

$\mathrm{H}_{2} \mathrm{O}_{2}$ of $0.2 \mathrm{mM}$ and $0.4 \mathrm{mM}$ increased the intracellular ROS level to $123 \%$ and $135 \%$ compared to the nontreated group, while ascorbic-acid-treated group showed reduced ROS level of $33 \%$ and $34 \%$, respectively (Figure 7A).

ARPE-19 cells were pretreated with either $20 \mu \mathrm{M}$ astaxanthin, $90 \mu \mathrm{M}$ ascorbic acid, or a mixture of $20 \mu \mathrm{M}$ astaxanthin and $90 \mu \mathrm{M}$ ascorbic acid. When cells were exposed to $0.2 \mathrm{mM} \mathrm{H}_{2} \mathrm{O}_{2}$ for $24 \mathrm{~h}$, the viability decreased to $75 \%$. The $20-\mu \mathrm{M}$-astaxanthin- and $90-\mu \mathrm{M}$-ascorbic-acid-treatment could increase the viability to $97 \%$ and $93 \%$, respectively. The mixture of $20 \mu \mathrm{M}$ astaxanthin and $90 \mu \mathrm{M}$ ascorbic acid increased the viability to $129 \%$ (Figure 7B). Each drug could also decrease the intracellular ROS level. When cells were treated with $0.2 \mathrm{mM} \mathrm{H}_{2} \mathrm{O}_{2}$ for $24 \mathrm{~h}$, the intracellular ROS level increased to $200 \%$. The $20-\mu \mathrm{M}$-astaxanthin- and $90-\mu \mathrm{M}$-ascorbic-acid-treatment reduced the ROS level to $169 \%$, and $135 \%$, respectively. The mixture of $20 \mu \mathrm{M}$ astaxanthin and $90 \mu \mathrm{M}$ ascorbic acid decreased the ROS level to $104 \%$ (Figure 7C). 
A

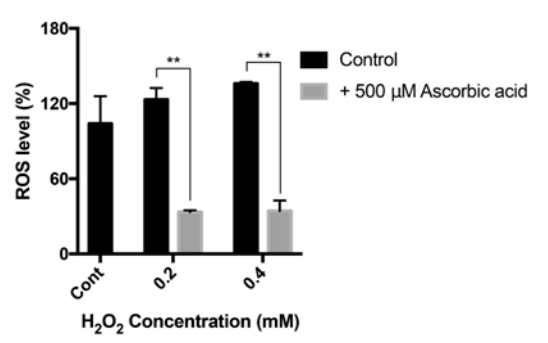

B

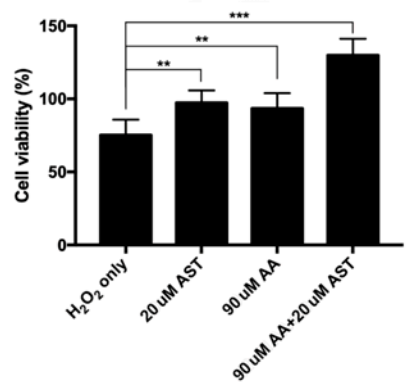

C

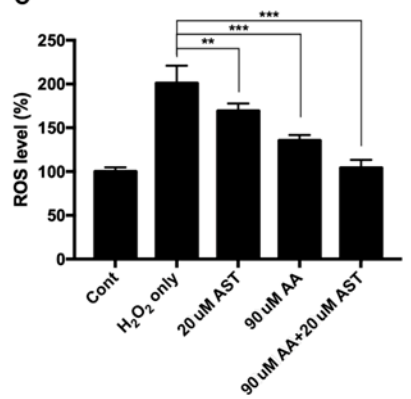

Figure 7. Intracellular ROS level and cell viability of ARPE-19 after $\mathrm{H}_{2} \mathrm{O}_{2}$ exposure with ascorbic acid and the mixture of ascorbic acid and astaxanthin. Ascorbic acid at $500 \mu \mathrm{M}$ significantly reduced the intracellular ROS level under sublethal and lethal dose of $\mathrm{H}_{2} \mathrm{O}_{2}(0.2-0.4 \mathrm{mM})$ compared to the control group without ascorbic acid treatment (A). The effect of $20 \mu \mathrm{M}$ astaxanthin, $90 \mu \mathrm{M}$ ascorbic acid, and the mixture of the two compounds on the cell viability of ARPE-19 under $\mathrm{H}_{2} \mathrm{O}_{2}$-induced oxidative stress was examined by MTT assay. Cell viability was significantly increased when the cells were pretreated with $20 \mu \mathrm{M}$ astaxanthin, $90 \mu \mathrm{M}$ ascorbic acid, and the mixture of the two compounds for $6 \mathrm{~h}$ and with $0.2 \mathrm{mM} \mathrm{H} \mathrm{O}_{2}$ for $24 \mathrm{~h}$, compared to $\mathrm{H}_{2} \mathrm{O}_{2}$ only (B). ROS level was significantly decreased when the cells were pretreated with $20 \mu \mathrm{M}$ astaxanthin, $90 \mu \mathrm{M}$ ascorbic acid, and the mixture of the two compounds for $6 \mathrm{~h}$ and with $0.2 \mathrm{mM} \mathrm{H}_{2} \mathrm{O}_{2}$ for $24 \mathrm{~h}$, compared to $\mathrm{H}_{2} \mathrm{O}_{2}$ only. Asterisks indicate a significant difference between increment in cell viability and reduction in intracellular ROS level compared to control cells only with $\mathrm{H}_{2} \mathrm{O}_{2}$ exposure without antioxidant treatment (C). $\left.{ }^{* *} p<0.01,{ }^{* * *} p<0.001\right)$. AST, astaxanthin; AA, ascorbic acid; ROS, reactive oxygen species; MTT, 3-(4,5-dimethylthiazol-2-yl)-2,5-diphenyltetrazolium bromide.

\section{Discussion}

In this study, antioxidative properties of ascorbic acid and astaxanthin were evaluated based on $\mathrm{H}_{2} \mathrm{O}_{2}$-induced and UVB-induced oxidative stress models within ARPE-19 cells. Studies have found that $\mathrm{H}_{2} \mathrm{O}_{2}$ and UVB have different effects on cells regarding oxidative stress. First, even directly adding $\mathrm{H}_{2} \mathrm{O}_{2}$ in the cell culture medium results in a short-term exposure because its concentration decreases rapidly in the presence of the cells. $\mathrm{H}_{2} \mathrm{O}_{2}$ can penetrate the cell easily, but it is also reduced rapidly by the antioxidative mechanism [29]. On the other hand, UVB has a lingering effect on the cells by directly damaging DNA, causing gene mutation, and modifying gene expression, and enzyme activity along with increasing ROS level [36]. UVB-induced damage is mediated by two different pathways. sne is by ROS generated immediately after the irradiation and the other is by reactive nitrogen species in the later time point [37]. As a result, even with a single and momentary exposure to UVB, the viability of the exposed cells decreases in the course of time [36].

Based on the precedent research, viability change of ARPE-19 cells was evaluated after $24 \mathrm{~h}$ for a $\mathrm{H}_{2} \mathrm{O}_{2}$ model and a UVB model [38]. $\mathrm{H}_{2} \mathrm{O}_{2}(0-0.8 \mathrm{mM})$ was exposed to ARPE-19 cells and their viability was dose-dependently reduced and intracellular ROS level was increased. UVB also reduced the cell viability and increased the intracellular ROS level but the $\mathrm{H}_{2} \mathrm{O}_{2}$ seemed to decrease the viability exponentially. One explanation can be that because $\mathrm{H}_{2} \mathrm{O}_{2}$ not only produces ROS, but it also affects junctional integrity of the RPE cell [39], weakening the cell adhesion to the bottom of the well-the cell viability assay result may have been affected. This can also explain the lower cell viability at $0.4 \mathrm{mM}$ of $\mathrm{H}_{2} \mathrm{O}_{2}$ than $40 \mathrm{~mJ} / \mathrm{cm}^{2}$ UVB even though cells with $\mathrm{H}_{2} \mathrm{O}_{2}$-induced oxidative stress have a lower ROS level.

Within the condition of sublethal and lethal doses of $\mathrm{H}_{2} \mathrm{O}_{2}$ and $\mathrm{UVB}$, antioxidative potencies of ascorbic acid and astaxanthin were evaluated. Although their antioxidative properties had been studied and have moved on to clinical level with patients with retinal diseases (Age-Related Eye Disease Study [AREDS] and Carotenoids in Age-Related Maculopathy Italian Study [CARMIS]) [40,41], there are controversies about whether they have a protective effect on cellular oxidative stress model. 
In one study, ascorbic acid did not have a protective effect on Fenton-reaction-mediated oxidative stress model of ARPE-19 but it rather decreased the cell survival ratio at a low concentration (0.1-1 mM) compared to the group without ascorbic acid [42]. This was also the case for a tert-butyl hydroperoxide ( $\mathrm{t}-\mathrm{BOOH})$-induced oxidative stress model. In a study by Kagan et al., ascorbic acid (0.02-0.2 mM) also decreased the cell viability of ARPE-19 with oxidative stress induced by t-BOOH [43]. The effect of $\mathrm{t}-\mathrm{BOOH}$ in porcine RPE also could not be diminished by ascorbic acid [44]. In our study, however, ascorbic acid increased the viability of the cells even at a low concentration where studies mentioned above suggest it decreases the viability and this was confirmed within two different oxidative stress models mediated by $\mathrm{H}_{2} \mathrm{O}_{2}$ and UVB. Although the central mechanism of $\mathrm{t}-\mathrm{BOOH}$ to induce oxidative stress is by generating alkyl radicals [45], $\mathrm{H}_{2} \mathrm{O}_{2}$ is the central redox signaling molecule in general [30] forming hydroxy radicals [46], which can react intracellularly to generate various radicals including alkyl radical [47]. Considering $\mathrm{H}_{2} \mathrm{O}_{2}$ model reproduces more general situation of oxidative stress, and UVB model mediates $\mathrm{H}_{2} \mathrm{O}_{2}$ as the central signaling molecule [48], our result based on both models is more convincing.

Ascorbic acid neutralized the effect of the oxidative stress inducer in both $\mathrm{H}_{2} \mathrm{O}_{2}$ and UVB model but astaxanthin only did so in UVB-induced stress model. Li et al. [38] investigated the effect of astaxanthin on ARPE-19 cells against oxidative stress with $\mathrm{H}_{2} \mathrm{O}_{2}$. They incubated ARPE-19 cells with $20 \mu \mathrm{M}$ astaxanthin for different lengths of time $\left(6,12\right.$, and $24 \mathrm{~h}$ ) and then exposed to $200 \mu \mathrm{M} \mathrm{H}_{2} \mathrm{O}_{2}$ for $24 \mathrm{~h}$. The cell viability increase was time-dependent, and they suggested that $24 \mathrm{~h}$ was the optimal time for astaxanthin treatment. In the current study, we incubated ARPE-19 cells with ascorbic acid or astaxanthin for $6 \mathrm{~h}$ and then exposed to $\mathrm{H}_{2} \mathrm{O}_{2}$ with antioxidants for $24 \mathrm{~h}$. Our findings that astaxanthin did not show significant effect on the cell viability with $\mathrm{H}_{2} \mathrm{O}_{2}$ exposure while it did show increased viability with UVB irradiation may be due to different lengths of time from those of Li et al. [38] for astaxanthin treatment. There is also another possibility that even if astaxanthin, an extremely lipophilic compound, was dissolved in DMSO, it may be possible that the efficiency was lower than the actual concentration in an aqueous environment such as cell culture medium.

The synergistic effect of ascorbic acid and astaxanthin was also evaluated in this study. The combination of ascorbic acid and astaxanthin showed better antioxidative effect compared to each drug alone. There are few reports that investigate the effective antioxidant action of ascorbic acid and astaxanthin in combination. In a study by Guerra et al. [49], the association of astaxanthin with ascorbic acid greatly improved neutrophil phagocytic capacity and decreased ROS with pro-inflammatory cytokines. They suggested that the astaxanthin/ascorbic acid system mimics the recycling system of vitamin E/vitamin C. Astaxanthin provides cell membranes with potent protection against free radicals or other oxidative attack. Moreover, previous studies confirm that astaxanthin has a large capacity to neutralize free radicals or other oxidant activity in the nonpolar zones of phospholipid aggregates, as well as along their polar boundary zones [50]. Ascorbic acid, in turn, promotes antioxidant effects mainly in a water-phase microenvironment. The exact mechanism other than reducing the intracellular ROS production is unknown through this study, but it is assumed that the two antioxidants exhibited synergistic effects through the mechanism identified in previous experimental studies.

An elevated level of ROS is always observed in the diabetic retina. Given that the administration of antioxidants in animal models preserves retinal capillaries from hyperglycemia-induced degeneration, ROS are considered a major causative factor involved in DR development [51,52]. Meanwhile, diabetes induces mitochondrial damage in the retina and its capillary cells and mitochondrial dysfunction is also considered to play a significant role in the development of DR [53,54]. The results of this study showed that antioxidants treatment resulted in significantly improved cell viability which is perhaps due to the improved mitochondrial function, improved cellular attachment performance, and increased growth rate of the cells. However, further investigation will be required to determine more precise mechanisms and effects of antioxidants on ARPE-19 cells.

Although the role of retinal endothelial cells comprising inner blood-retinal barriers (BRB) is important in DR development, the role of RPE cells comprising outer BRB is also crucial. The flow 
of nutrients materials, metabolites, ions, proteins, and water flux to and from the retina is regulated by these two BRBs and disruption of inner and outer BRB causes retinal hyperpermeability and development of diabetic macular edema, which is a leading cause of vision loss in DR [55]. Therefore, current study using ARPE-19 cells is thought be closely related to BRB breakdown and the pathogenesis of DR. Oxidative damage to cells is commonly modeled using treatment with $\mathrm{H}_{2} \mathrm{O}_{2}$ for a long time [56,57], however, very little is known about the role of UV irradiation on ARPE-19 cells and especially on the development of DR. A recent population-based study investigated the association between daily sunlight exposure duration and DR [58]. The authors suggested that the risk of DR was 2.66 times higher in the group with $\geq 5 \mathrm{~h}$ of daily sunlight exposure than in the group with less exposure after adjusting for risk factors such as duration of diabetes, serum hemoglobin A1c level, hypertension, and dyslipidemia. Although a lot of evidence is still lacking, the results of the current study can be used as evidence that the effects of oxidative stress induced by $\mathrm{H}_{2} \mathrm{O}_{2}$ or UVB irradiation on the development of DR as well as the antioxidants can reduce disruption of outer BRB, which is represented by the viability of ARPE-19 cells.

This study successfully established an oxidative stress model of RPE which can be used to test potential antioxidative compounds. Since it has been known that oxidative stress is closely linked to diabetic retinopathy, identifying antioxidants like ascorbic acid and astaxanthin used in this study can also be beneficial to patients with diabetic retinopathy.

\section{Conclusions}

In summary, the antioxidative effect of ascorbic acid and astaxanthin was evaluated in this study using two different oxidative stress models achieved by $\mathrm{H}_{2} \mathrm{O}_{2}$ and UVB. Despite controversies questioning the antioxidative property of ascorbic acid, it was shown in this study that ascorbic acid diminishes the oxidative damage within human RPE oxidative stress models of $\mathrm{H}_{2} \mathrm{O}_{2}$ and UVB which reflect general circumstance of oxidatively stressed environment. This study also showed the ROS scavenging capacity of astaxanthin in a UVB-induced stress model. Synergistic effect of ascorbic acid and astaxanthin was also shown resulting in increment in cell viability and reduction in intracellular ROS level.

Author Contributions: S.O. performed the experiment and wrote the manuscript; Y.J.K. performed the experiment; E.K.L. reviewed, wrote, and edited the manuscript; S.W.P. designed the experiment; H.G.Y. designed all experiments and reviewed the manuscript. All authors have read and agreed to the published version of the manuscript.

Funding: This research was supported by a grant of the Korea Health Technology R\&D Project through the Korea Health Industry Development Institute (KHIDI), funded by the Ministry of Health \& Welfare, Republic of Korea (grant number: HI14C1277).

Conflicts of Interest: The authors declare no conflict of interest.

\section{References}

1. Klein, B.E. Overview of epidemiologic studies of diabetic retinopathy. Ophthalmic Epidemiol. 2007, 14, 179-183. [CrossRef] [PubMed]

2. Safi, S.Z.; Qvist, R.; Kumar, S.; Batumalaie, K.; Ismail, I.S. Molecular mechanisms of diabetic retinopathy, general preventive strategies, and novel therapeutic targets. Biomed. Res. Int. 2014, 2014, 801269. [CrossRef] [PubMed]

3. Chiu, C.J.; Taylor, A. Dietary hyperglycemia, glycemic index and metabolic retinal diseases. Prog. Retin. Eye Res. 2011, 30, 18-53. [CrossRef] [PubMed]

4. Nishikawa, M.; Inoue, M. Oxidative stress and tissue injury. Masui 2008, 57, 321-326.

5. Naruse, R.; Suetsugu, M.; Terasawa, T.; Ito, K.; Hara, K.; Takebayashi, K.; Morita, K.; Aso, Y.; Inukai, T. Oxidative stress and antioxidative potency are closely associated with diabetic retinopathy and nephropathy in patients with type 2 diabetes. Saudi Med. J. 2013, 34, 135-141. 
6. Limón-Pacheco, J.; Gonsebatt, M.E. The role of antioxidants and antioxidant-related enzymes in protective responses to environmentally induced oxidative stress. Mutat. Res. Genet. Toxicol. Environ. Mutagen. 2009, 674, 137-147. [CrossRef] [PubMed]

7. Valle, I.; Álvarez-Barrientos, A.; Arza, E.; Lamas, S.; Monsalve, M. PGC- $1 \alpha$ regulates the mitochondrial antioxidant defense system in vascular endothelial cells. Cardiovasc. Res. 2005, 66, 562-573. [CrossRef]

8. De Vries, H.E.; Witte, M.; Hondius, D.; Rozemuller, A.J.; Drukarch, B.; Hoozemans, J.; van Horssen, J. Nrf2-induced antioxidant protection: A promising target to counteract ROS-mediated damage in neurodegenerative disease? Free Radic. Biol. Med. 2008, 45, 1375-1383. [CrossRef]

9. Slemmer, J.E.; Shacka, J.J.; Sweeney, M.; Weber, J.T. Antioxidants and free radical scavengers for the treatment of stroke, traumatic brain injury and aging. Curr. Med. Chem. 2008, 15, 404-414.

10. Moradas-Ferreira, P.; Costa, V.; Piper, P.; Mager, W. The molecular defences against reactive oxygen species in yeast. Mol. Microbiol. 1996, 19, 651-658. [CrossRef]

11. Gultekin, F.; Delibas, N.; Yasar, S.; Kilinc, I. In vivo changes in antioxidant systems and protective role of melatonin and a combination of vitamin $\mathrm{C}$ and vitamin $\mathrm{E}$ on oxidative damage in erythrocytes induced by chlorpyrifos-ethyl in rats. Arch. Toxicol. 2001, 75, 88-96. [CrossRef] [PubMed]

12. Busik, J.V.; Mohr, S.; Grant, M.B. Hyperglycemia-induced reactive oxygen species toxicity to endothelial cells is dependent on paracrine mediators. Diabetes 2008, 57, 1952-1965. [CrossRef] [PubMed]

13. Okoduwa, S.I.; Umar, I.A.; Ibrahim, S.; Bello, F.; Habila, N. Age-dependent alteration of antioxidant defense system in hypertensive and type-2 diabetes patients. J. Diabetes Metab. Disord. 2015, 14, 32. [CrossRef]

14. Luo, L.; Chen, H.; Trush, M.A.; Show, M.D.; Anway, M.D.; Zirkin, B.R. Aging and the brown Norway rat leydig cell antioxidant defense system. J. Androl. 2006, 27, 240-247. [CrossRef]

15. Liguori, I.; Russo, G.; Curcio, F.; Bulli, G.; Aran, L.; Della-Morte, D.; Gargiulo, G.; Testa, G.; Cacciatore, F.; Bonaduce, D.; et al. Oxidative stress, aging, and diseases. Clin. Interv. Aging 2018, 13, 757. [CrossRef] [PubMed]

16. Halliwell, B. Antioxidants in human health and disease. Ann. Rev. Nutr. 1996, 16, 33-50. [CrossRef]

17. Noctor, G.; Foyer, C.H. Ascorbate and glutathione: Keeping active oxygen under control. Ann. Rev. Plant Biol. 1998, 49, 249-279. [CrossRef] [PubMed]

18. Naguib, Y.M. Antioxidant activities of astaxanthin and related carotenoids. J. Agric. Food Chem. 2000, 48, 1150-1154. [CrossRef]

19. Gil, M.I.; Tomás-Barberán, F.A.; Hess-Pierce, B.; Kader, A.A. Antioxidant capacities, phenolic compounds, carotenoids, and vitamin C contents of nectarine, peach, and plum cultivars from California. J. Agric. Food Chem. 2002, 50, 4976-4982. [CrossRef]

20. Marc, F.; Davin, A.; Deglène-Benbrahim, L.; Ferrand, C.; Baccaunaud, M.; Fritsch, P. Studies of several analytical methods for antioxidant potential evaluation in food. Med. Sci. 2004, 20, 458-463.

21. Ou, B.; Hampsch-Woodill, M.; Flanagan, J.; Deemer, E.K.; Prior, R.L.; Huang, D. Novel fluorometric assay for hydroxyl radical prevention capacity using fluorescein as the probe. J. Agric. Food Chem. 2002, 50, 2772-2777. [CrossRef] [PubMed]

22. Denev, P.; Ciz, M.; Ambrozova, G.; Lojek, A.; Yanakieva, I.; Kratchanova, M. Solid-phase extraction of berries' anthocyanins and evaluation of their antioxidative properties. Food Chem. 2010, 123, 1055-1061. [CrossRef]

23. Cao, G.; Prior, R.L. Comparison of different analytical methods for assessing total antioxidant capacity of human serum. Clin. Chem. 1998, 44, 1309-1315. [CrossRef] [PubMed]

24. Ozcan, T.; Sahin, S.; Akpinar-Bayizit, A.; Yilmaz-Ersan, L. Assessment of antioxidant capacity by method comparison and amino acid characterisation in buffalo milk kefir. Int. J. Dairy Technol. 2019, 72, 65-73. [CrossRef]

25. Rao, P.S.; Kiranmayi, V.; Swathi, P.; Jeyseelan, L.; Suchitra, M.; Bitla, A.R. Comparison of two analytical methods used for the measurement of total antioxidant status. J. Antioxid. Act. 2015, 1, 22.

26. Roy, M.K.; Koide, M.; Rao, T.P.; Okubo, T.; Ogasawara, Y.; Juneja, L.R. ORAC and DPPH assay comparison to assess antioxidant capacity of tea infusions: Relationship between total polyphenol and individual catechin content. Int. J. Food Sci. Nutr. 2010, 61, 109-124. [CrossRef]

27. Valverde Malaver, C.L.; Colmenares Dulcey, A.J.; Isaza Martínez, J.H. Comparison of DPPH free radical scavenging, ferric reducing antioxidant power (FRAP), and total phenolic content of two meriania species (Melastomataceae). Rev. Cienc. 2015, 19, 117-124. [CrossRef] 
28. Rácz, A.; Papp, N.; Balogh, E.; Fodor, M.; Héberger, K. Comparison of antioxidant capacity assays with chemometric methods. Anal. Methods 2015, 7, 4216-4224. [CrossRef]

29. Gille, J.; Joenje, H. Cell culture models for oxidative stress: Superoxide and hydrogen peroxide versus normobaric hyperoxia. Mutat. Res. DNAging. 1992, 275, 405-414. [CrossRef]

30. Sies, H. Hydrogen peroxide as a central redox signaling molecule in physiological oxidative stress: Oxidative eustress. Red. Biol. 2017, 11, 613-619. [CrossRef]

31. Wijeratne, S.S.; Cuppett, S.L.; Schlegel, V. Hydrogen peroxide induced oxidative stress damage and antioxidant enzyme response in Caco-2 human colon cells. J. Agric. Food Chem. 2005, 53, 8768-8774. [CrossRef] [PubMed]

32. Glickman, R.D. Ultraviolet phototoxicity to the retina. Eye Contact Lens 2011, 37, 196-205. [CrossRef] [PubMed]

33. Podda, M.; Traber, M.G.; Weber, C.; Yan, L.J.; Packer, L. UV-irradiation depletes antioxidants and causes oxidative damage in a model of human skin. Free Radic. Biol. Med. 1998, 24, 55-65. [CrossRef]

34. Wenk, J.; Brenneisen, P.; Meewes, C.; Wlaschek, M.; Peters, T.; Blaudschun, R.; Ma, W.; Kuhr, L.; Schneider, L.; Scharffetter-Kochanek, K.; et al. UV-induced oxidative stress and photoaging. Curr. Probl. Dermatol. 2001, 29, 83-94. [PubMed]

35. Cai, J.; Qi, X.; Kociok, N.; Skosyrski, S.; Emilio, A.; Ruan, Q.; Han, S.; Liu, L.; Chen, Z.; Rickman, C.B.; et al. $\beta$-Secretase (BACE1) inhibition causes retinal pathology by vascular dysregulation and accumulation of age pigment. EMBO Mol. Med. 2012, 4, 980-991. [CrossRef]

36. Zhao, L.; Man, Y.; Liu, S. Long non-coding RNA HULC promotes UVB-induced injury by up-regulation of BNIP3 in keratinocytes. Biomed. Pharmacother. 2018, 104, 672-678. [CrossRef]

37. Terra, V.; Souza-Neto, F.; Pereira, R.; Silva, T.; Costa, A.; Luiz, R.; Cecchini, R.; Cecchini, A. Time-dependent reactive species formation and oxidative stress damage in the skin after UVB irradiation. J. Photochem. Photobiol. B Biol. 2012, 109, 34-41. [CrossRef]

38. Li, Z.; Dong, X.; Liu, H.; Chen, X.; Shi, H.; Fan, Y.; Hou, D.; Zhang, X. Astaxanthin protects ARPE-19 cells from oxidative stress via upregulation of Nrf2-regulated phase II enzymes through activation of PI3K/Akt. Mol. Vis. 2013, 19, 1656-1666.

39. Bailey, T.A.; Kanuga, N.; Romero, I.A.; Greenwood, J.; Luthert, P.J.; Cheetham, M.E. Oxidative stress affects the junctional integrity of retinal pigment epithelial cells. Investig. Ophthalmol. Vis. Sci. 2004, 45, 675-684. [CrossRef]

40. Glaser, T.S.; Doss, L.E.; Shih, G.; Nigam, D.; Sperduto, R.D.; Ferris, F.L., 3rd; Agron, E.; Clemons, T.E.; Chew, E.Y. Age-related eye disease study research, g. the association of dietary lutein plus Zeaxanthin and B vitamins with cataracts in the age-related eye disease study: AREDS report no. 37. Ophthalmology 2015, 122, 1471-1479. [CrossRef]

41. Piermarocchi, S.; Saviano, S.; Parisi, V.; Tedeschi, M.; Panozzo, G.; Scarpa, G.; Boschi, G.; Lo Giudice, G.; Carmis Study, G. Carotenoids in Age-related Maculopathy Italian Study (CARMIS): Two-year results of a randomized study. Eur. J. Ophthalmol. 2012, 22, 216-225. [PubMed]

42. Zeitz, O.; Schlichting, L.; Richard, G.; Strauß, O. Lack of antioxidative properties of vitamin C and pyruvate in cultured retinal pigment epithelial cells. Graefe Arch. Clin. Exp. Ophthalmol. 2007, 245, 276-281. [CrossRef] [PubMed]

43. Kagan, D.B.; Liu, H.; Hutnik, C.M. Efficacy of various antioxidants in the protection of the retinal pigment epithelium from oxidative stress. Clin. Ophthalmol. 2012, 6, 1471. [PubMed]

44. Woo, K.I.; Lee, J. The effects of ascorbic acid on free radical injury in cultured retinal pigment epithelial cells. Korean J. Ophthalmol. 1995, 9, 19-25. [CrossRef] [PubMed]

45. Korte, C.S. Tert-Butyl Hydroperoxide Stimulates Parturition-Associated Pathways in a Human Placental Cell Line. Ph.D Thesis, University of Michigan, Ann Arbor, MI, USA, 17 September 2013.

46. Wang, Y.; Branicky, R.; Noë, A.; Hekimi, S. Superoxide dismutases: Dual roles in controlling ROS damage and regulating ROS signaling. J. Cell Biol. 2018, 217, 1915-1928. [CrossRef]

47. McKetta, J., Jr. Encyclopedia of Chemical Processing and Design: Volume 65-Waste: Nuclear Reprocessing and Treatment Technologies to Wastewater Treatment: Multilateral Approach; Routledge: London, UK, 2017.

48. Masaki, H.; Atsumi, T.; Sakurai, H. Detection of hydrogen peroxide and hydroxyl radicals in murine skin fibroblasts under UVB irradiation. Biochem. Biophys. Res. Commun. 1995, 206, 474-479. [CrossRef]

49. Guerra, B.A.; Bolin, A.P.; Otton, R. Carbonyl stress and a combination of astaxanthin/vitamin C induce biochemical changes in human neutrophils. Toxicol Vitro. 2012, 26, 1181-1190. [CrossRef] 
50. Fassett, R.G.; Coombes, J.S. Astaxanthin: A potential therapeutic agent in cardiovascular disease. Mar. Drugs. 2011, 9, 447-465. [CrossRef]

51. Kowluru, R.A.; Tang, J.; Kern, T.S. Abnormalities of retinal metabolism in diabetes and experimental galactosemia. VII. Effect of long-term administration of antioxidants on the development of retinopathy. Diabetes 2001, 50, 1938-1942. [CrossRef]

52. Kanwar, M.; Chan, P.S.; Kern, T.S.; Kowluru, R.A. Oxidative damage in the retinal mitochondria of diabetic mice: Possible protection by superoxide dismutase. Investig. Ophthalmol. Vis. Sci. 2007, 48, 3805-3811. [CrossRef]

53. Kowluru, R.A.; Abbas, S.N. Diabetes-induced mitochondrial dysfunction in the retina. Investig. Ophthalmol. Vis. Sci. 2003, 44, 5327-5334. [CrossRef] [PubMed]

54. Kowluru, R.A. Diabetic retinopathy: Mitochondrial dysfunction and retinal capillary cell death. Antioxid Redox. Signal 2005, 7, 1581-1587. [CrossRef] [PubMed]

55. Wang, M.H.; Hsiao, G.; Al-Shabrawey, M. Eicosanoids and oxidative stress in diabetic retinopathy. Antioxidants 2020, 9, 520. [CrossRef] [PubMed]

56. Kaczara, P.; Sarna, T.; Burke, J.M. Dynamics of H2O2 availability to ARPE-19 cultures in models of oxidative stress. Free Radic. Biol. Med. 2010, 48, 1064-1070. [CrossRef]

57. Zheng, Y.; Liu, Y.; Ge, J.; Wang, X.; Liu, L.; Bu, Z.; Liu, P. Resveratrol protects human lens epithelial cells against $\mathrm{H}_{2} \mathrm{O}_{2}$-induced oxidative stress by increasing catalase, SOD-1, and HO-1 expression. Mol. Vis. 2010, 16, 1467-1474. [PubMed]

58. Lee, H.J.; Kim, C.O.; Lee, D.C. Association between daily sunlight exposure duration and diabetic retinopathy in Korean adults with diabetes: A nationwide population-based cross-sectional study. PLoS ONE 2020, 15, e0237149. [CrossRef]

(C) 2020 by the authors. Licensee MDPI, Basel, Switzerland. This article is an open access article distributed under the terms and conditions of the Creative Commons Attribution (CC BY) license (http://creativecommons.org/licenses/by/4.0/). 